\title{
DAMPAK PENGARUH PEMBIAYAAN MURABAHAH TERHADAP PERKEMBANGAN UMKM SELAMA PANDEMI COVID-19
}

\author{
Dhoqi Dofiria \\ Istianah $^{b}$ \\ Ridan Muhtadic
}

a Universitas Islam Negeri Sunan Ampel, Surabaya

bSekolah Tinggi Agama Islam Al-Falah, Pamekasan

cSekolah Tinggi Agama Islam Miftahul Ulum, Pamekasan

Email: doqidofiri@gmail.com; istinfawwaz@gmail.com;

ridanmuhtadi@gmail.com

\begin{abstract}
Introduction: The background of study is stimulated by the existance of micro-financing by using al-murabahah agreement at PT BRI Syariah branch of Bangkalan which is distributed to business people on level of medium, small and micro who need loan as the additional venture capital. Based on the explanation above, the research problems are; the condition of UMKM customers at BRI Syariah, especially the bangkalan people and the influence of Murabahah financing conducted by BRI Syariah on UMKM people in Bangkalan

Methods: The study applies the quantitative design in which the data collecting technique used are documentation, interview and questionnaire. Data analysis and processing technique used are SPSS which consist of simple linear regression, correlation test, ttest and excel percentage. The implementation time of this research was carried out in October 2020.

Results: The result of the study are: (1) the actors of medium, small and micro business level in bangkalan have taken the murabahah financing at PT. BRI Syariah branch of Bangkalan as the additional venture capital that they has run, and (2) murabahah financing at PT. BRI Syariah branch of Bangkalan is very influential on the development of UMKM people in Bangkalan. It can be measure by the increasing of the income as $236 \% . s$
\end{abstract}


Keywords: Micro, Small and Medium Enterprises (MSMEs), almurabahah finance, income, UMKM development.

\section{PENDAHULUAN}

Ekonomi di Indonesia dari tahun ke tahun selalu mengalami kenaikan. Pada tahun 2017 pertumbuhan ekonomi mencapai 5,07 persen dan pada tahun 2018 mencapai 5,17 persen, yang berarti dari rentang tahun 2018 sampai 2019 mengalami kenaikan. ${ }^{1}$ Adapun kenaikan pertumbuhan ekonomi tersebut dipengaruhi oleh dari berbagai sektor yang salah satu diantaranya adalah di sektor perdagangan. ${ }^{2}$

Bagian dari perdagangan tersebut adalah UMKM yaitu Usaha Mikro Kecil Menengah. Dalam perekonomian Indonesia UMKM berperan sebagai penyumbang pendapatan yang lumayan besar, pada data BPS tahun 2020 tercatat UMKM ditahun 2019 memperoleh pendapatan sebesar 18 triliun. Ini berarti UMKM memiliki peluang yang sangat besar dalam meningkatkan pertumbuhan ekonomi.

Dalam penelitian Van Gils dalam Aylin Ates dan Umit Bititci menyatakan bahawa UMKM adalah mesin penting untuk merangsang pertumbuhan ekonomi suatu Negara. peran Usaha Mikro Kecil Menengah (UMKM) dalam perekonomian Indonesia paling tidak dapat dilihat dari (1) kedudukan sebagai pemain utama dalam kegiatan ekonomi di berbagai sektor, (2) penyedia lapangan kerja yang terbesar, (3) pemain penting dalam perkembangan kegiatan ekonomi lokal dan pemberdayaan masyarakat, (4) pencipta pasar baru dan sumber inovasi, serta (5) sumbangannya dalam menjaga neraca pembayaran melalui kegiatan ekspor. Posisi penting ini sejak dilanda krisis belum semuanya berhasil dipertahankan

\footnotetext{
${ }^{1}$ Badan Pusat Statistik No. 16/02/Th. XVII, 5 Februari 2019.

I Ibid, No. 63/08/Th. XVII, 5 Agustus 2019
} 
sehingga pemulihan ekonomi belum optimal. (Departemen Koperasi, 2010). ${ }^{3}$

Di era krisis yang banyak berimbas pada PHK di sejumlah perusahaan mendorong para karyawan yang telah diputus kontraknya untuk berwirausaha seperti membuka usaha di bidang kuliner, kerajinan tangan dan lain sebagainya. Dari kegiatan tersebut dapat memberikan sumber penghasilan bagi dirinya sendiri dan orang lain, dan secara makro ekonomi dapat menyerap tenaga kerja serta dapat memberikan sumbangan dalam penciptaan pendapatan nasional dari kegiatan UMKM yang pada gilirannya akan berdampak pada pertumbuhan ekonomi yang membaik dan peningkatan pemerataan pendapatan. ${ }^{4}$

Potensi UMKM di Indonesia dengan jumlah Unit Usaha Kredit Mikro, Kecil, dan Menengah mencapai hampir 50 juta unit di Indonesia. Lapangan kerja Usaha Mikro dan Kecil di Indonesia diperkirakan menyumbang sekitar 53\% dari total produk Bruto Indonesia dan kontribusi ekspor sebesar 20,52\%. Sementara dari penyerapan tenaga kerja, Usaha Mikro menyerap 77 juta lebih tenaga kerja dan Usaha Kecil sekitar 10 juta sedangkan Usaha Menengah hampir 5 juta tenaga kerja. Dengan perkiraan 50 juta UMKM di Indonesia, berarti penambahan 1 tenaga kerja dalam setiap unit saja sudah berarti sekitar 50 lapangan kerja baru. kalau tambah tenaga kerja 1 saja setiap usaha, maka terdapat 43 juta lapangan kerja baru yang diciptakan Usaha Mikro, kata Bambang Ismawan, Sekjen Gema PKM yang memperkirakan terdapat 43 juta Usaha Mikro di Indonesia, dan itu tanpa kerja keras pemerintah,

\footnotetext{
${ }^{3}$ Ade Raselawati," Pengaruh perkembangan Usaha Kecil Menengah terhadap pertumbuhan ekonomi pada sektor UKM di Indonesia", Skripsi, hlm 3.

4 Sri Wahyuningsih,"Dosen Fakultas Pertanian Universitas Wahid Hasim", Jurnal Peranan UKM Dalam Perekonomian Indonesia, hal, 10.
} 
karena yang diperlukan hanyalah membuat mekanisme agar Usaha Mikro hidup dan berkembang. ${ }^{5}$

Perkembangan potensi Usaha Mikro, Kecil dan Menengah (UMKM) di Indonesia tidak terlepas dari dukungan perbankan dalam penyaluran kredit kepada UMKM dan juga pemerintah. Kredit UMKM adalah kredit kepada debitur Usaha Mikro, Kecil dan Menengah yang memenuhi definisi dan kriteria Usaha Mikro, Kecil dan Menengah sebagaimana di atur dalam UU No. 20 Tahun 2008 Tentang UMKM. ${ }^{6}$ Pada UndangUndang tersebut dijelaskan beberapa pasal yang menjelaskan secara mendetail terkait dengan definisi UMKM, tujuan pemberdayaan dan lain sebagainya, dan lahirnya UndangUndang ini secara tidak langsung memberikan dukungan yang cukup signifikan terhadap eksistensi dalam perkembangan UMKM.

Support regulasi pemerintah terhadap perkembangan potensi UMKM salah satunya dapat dilihat dari pasal 4 (c) yang menyatakan bahwa salah satu prinsip dan tujuan pemberdayaan UMKM adalah dengan mementingkan potensipotensi yang ada di daerah-daerah. Ini berarti bahwa tiap - tiap daerah secara otomatis akan meningkatkan potensi - potensi daerah yang ada melalui UMKM sehingga dengan demikian akan tercipta peningkatan peran Usaha Mikro, Kecil dan Menengah dalam pembangunan daerah, yang juga akan menciptakan lapangan kerja, pemerataan pendapatan, pertumbuhan ekonomi, dan pengentasan dari kemiskinan. ${ }^{7}$

Di daerah kabupaten Bangkalan, sedikitnya sudah ada 121.216 Usaha Mikro Kecil dan Menengah (UMKM). Namun,

\footnotetext{
5 BBC,"Potensi UMKM di Indonesia", dalam www. bbcIndonesia.com. dalam www.bbc.com. Publis tanggal 01 desember 2008 (15:44 GMT). Akses tanggal 19 Desember 2014.

6 Bank Indonesia,"kredit UMKM", dalam www.bi.go.id. Publis 2013. Akses tanggal 19 Desember 2014.

${ }^{7}$ Undang-Undang Republik Indonesia Nomor 20 Tahun 2008,"Usaha Mikro, Kecil, dan Menengah".
} 
jumlah UMKM tersebut dinilai masih kecil, karena itu Dinas Koperasi (Diskop) UMKM Bangkalan menargetkan harus ada penambahan 1000 unit usaha baru tiap tahun. ${ }^{8}$ Kepala Dinas koperasi UMKM Bangkalan Andang Pradana mengatakan bahwa keberadaan UMKM bisa menjadi tolak ukur kemajuan perekonomian suatu daerah. Beliau memaparkan bahwa perekonomian akan semakin bagus jika banyak UMKM bermunculan. Dinas Koperasi Bangkalan menargetkan bahwa di kabupaten Bangkalan tiap tahun harus ada 1000 unit usaha baru. ${ }^{9}$

Untuk mewujudkan target tersebut, Diskop UMKM Bangkalan menjalankan sejumlah kebijakan yang salah satu diantaranya menyediakan fasilitas memadai bagi pelaku UMKM seperti dibangunnya pusat makanan rakyat (Pumara) disebelah stadion glora bangkalan (SGB). ${ }^{10}$ Selain fasilitas yang dibutuhkan , tambahan modal juga sangat diperlukan untuk meningkatkan Usaha yang dijalankan oleh para UMKM, yang bisa mewujudkan hal tersebut adalah perusahaan-perusahaan yang dapat memberikan pinjaman dana ataupun pembiayaan, salah satunya pada PT. BRI Syari'ah KCP Bangkalan dengan produk yang biasa dikenal yaitu pembiayaan murabahah.

Pembiayaan murabahah ini merupakan pembiayaan yang paling diminati oleh pelaku UMKM, setidaknya ini yang terjadi di PT. BRI Syari'ah KCP Bangkalan. Kecenderungan penggunaan pembiayaan murabahah ini disebabkan sisi syari'ah yang ada dalam akad pembiayaan tersebut, penentuan marginnya lebih rendah, resiko pembiayaan lebih kecil sekaligus biaya administrasi yang cukup rendah. Selain itu jika terjadi kegagalan dalam suatu usaha pada UMKM pihak bank menjamin ikut andil dalam hal tersebut karena selama

\footnotetext{
8 Jawa Pos,"Radar Madura", dalam www.radarmadura.co.id. Publis 3 April 2014 (07:04). Akses 19 september 2020.

${ }^{9}$ Ibid.

10 Ibid.
} 
pembiayaan berjalan pihak bank juga mengontrol dan membimbing perkembangan Usaha-Usaha yang di jalaninya oleh nasabah. ${ }^{11}$

\section{KAJIAN PUSTAKA}

\section{Al-Murabahah}

al-Murabahah adalah jual beli barang yang harga asalnya dengan tambahan keuntungan yang disepakati. Secara bahasa kata " murabahah" berasal dari bahasa Arab dengan asal kata (رَبَحَيُرَبْحُرَبَحً) yang berarti berntung atau mendapatkan laba. ${ }^{12}$ Sedangkan secara terminologi, definisi murabahah:

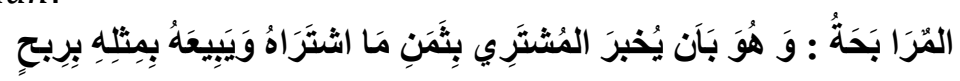
"Murabahah adalah akad jual beli barang dengan menyatakan tsaman (harga perolehan) dan ribh (keuntungan/Margin) yang disepakati oleh penjual dan pembeli"13

Kemudian ada beberapa definisi Bai' Mura>bah\}ah yang dikemukakan oleh :

a. Menurut Sayyid Sabiq didalam kitabnya fiqh sunnah Murabahah adalah penjualan dan harga pembelian barang berikut keuntungan yang diketahui. ${ }^{14}$

b. Menurut Ibnu Rusyd dalam kitabnya Bidayatul Mujtahid, Murabahah adalah jika penjual menyebutkan harga pembelian barang kepada

\footnotetext{
11Wawancara dengan Bapak Arief Cahyo (Bagian Penaksir Emas di Unit Gadai PT. BRI Syari'ah KCP Bangkalan), di Kantor PT. BRI Syari'ah KCP Bangkalan, tanggal 5 Desember 2014.

12 Ahmad Warson Munawwira, Al Munawwir kamus Arab-Indonesia, (Yogyakarta: Pustaka Progresif, 1997),hlm. 463.

13 Dumairi Nor, dkk, ekonomi Syariah Versi Salaf, (Sidogiri: Pustaka Sidogiri, 2007) hlm 40.

14 Sayyid Sabiq, Fiqh Sunnah Terjemahan Kamaluddin Jilid 12, (Bandung: Al-Ma'rif, 1995), hlm. 47.
} 
pembeli, kemudian ia menyaratkan atas labanya dalam jumlah tertentu, dinar atau dirham. ${ }^{15}$

Adapun dari referensi yang lain murabahah adalah berasal dari perkatan Ribh yang berarti pertambahan. Secara terminologi diartikan sebagai suatu penjualan barang seharga barang tersebut ditambah dengan keuntungan yang disepakati. Misalnya seseorang membeli barang kemudian menjualnya kembali dengan keuntungan tertentu. Dalam ungkapan lain, Ibn Rusyd mengartikan mura>bah\}ah sebagai jual beli barang pada harga asal dengan tambahan keuntungan yang disepakati. Dari pengertian yang menyatakan adanya keuntungan yang disepakati, murabahah memiliki karakter yaitu si penjual harus memberitahu kepada pembeli tentang harga pembelian barang dan juga menyatakan jumah keuntungan yang ditambahkan pada biaya tersebut. Perhitungan keuntungan bisa berdasarkan kepada jumlah harga atau kadar persentase tertentu. ${ }^{16}$ Murabahah dapat dilakukan secara tunai, bisa juga secara bayar tangguh atau bayar dengan angsuran. ${ }^{17}$

Transaksi murabahah ini, tidak pernah secara langsung dibicarakan dalam al-Quran, kecuali tentang jual beli secara umum, laba dan rugi, serta perdagangan. Demikian juga halnya dengan Hadist Rasulullah SAW, kecuali tentang jual beli secara angsur yang lazim dilaksanakan oleh Nabi SAW dan para Sahabatnya. Sebagaimana yang terungkap dalam sabdanya yang diriwayatkan oleh Ibn Majah dari Shuhaib Al-Rumi bahwa Rasulullah SAW bersabda :

15 Ibnu Rusyd, Terjemahan Bidayatul Mujtahid jilid III, (Semarang: As-Syifa', 1990), hlm. 181.

16 Syukri iska, Sistem Perbankan Syariah Di Indonesia, (Ygogyakarta: Fajar Media Pers, 2012). hal, 200.

17 Sutedi, Adrian, Perbankan Syari'ah tinjauan dan beberapa segi hukum, (Bogor : Ghalia Indonesia, 2004), hal. 95. 


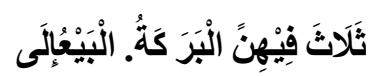

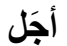

Artinya : "tiga hal yang didalamnya terdapat keberkahan; jual beli secara tangguh,"18

Transaksi murabahah, penjualan barang dengan menyatakan harga perolehan dan keuntungan yang disepakati oleh penjual dan pembeli. Penjual harus memberitahu harga produk yang dibeli dan menentukan suatu tingkat keuntungan sebagai tambahannya. Murabahah bisa dilakukan oleh perusahaan trading yang melakukan aktivitas bisnisnya dengan cara membeli barang, kemudian menjual kembali tanpa melakukan perubahan barang tersebut. Bank syari'ah mengadopsi transaksi ini, kaitannya dengan kebutuhan nasabah untuk memiliki barang tertentu tetapi tidak cukup memiliki dana sehingga bank syari'ah bisa memenuhi kebutuhan nasabah dengan skim bai' al-Murabahah. Pada mekanisme transaksi ini, bank syari'ah melakukan akad dengan nasabah kemudian bank syari'ah membeli barang yang dibutuhkan oleh nasabah kepada supplier secara tunai, setelah itu bank syari'ah menjual kepada nasabah dengan pembayaran angsuran. ${ }^{19}$

Ternyata dalam kenyataannya pembiayaan dengan prinsip jual beli (murabahah) paling banyak diterapkan dalam perbankan syariah atau memiliki porsi terbesar dibanding pembiayaan dengan prinsip yang lain. Dan pada umumnya menggunakan pembiayaan dengan prinsip murabahah sebagai metode pembiayaan utama. ${ }^{20}$

Meskipun demikian, mekanisme pembiayaan murabahah ini, ternyata tak lepas dari kecaman dan kritikan

18 HhafiZ Abi 'Abdillah Muhammad bin Yasi>d al-Qozwi>n, Sunan Ibnu Majah,(Bairut: Darul Fikr)no : 2289.

19 Wiyono Slamet, Maulamin Taufan, Akuntansi Syariah di Indonesia, (Jakarta: Penerbit Mitra Wacana Media, 2012). hal, 135.

${ }^{20}$ Anita Rahmawati, Ekonomi Syariah: Tinjauan Kritis Produk Murabahah dalam Perbankan Syariah di Indonesia,( La_Riba 2007), hlm. 188-189. 
dari para Ilmuwan Muslim sendiri. Mereka berpendapat bahwa bank-bank syari'ah dalam menjalankan kegiatan usahanya, ternyata bukannya meniadakan bunga dan membagi resiko, tetapi tetap mempertahankan praktek pembebanan bunga, namun dengan label Islam. ${ }^{21}$

Jual beli secara kredit disunnahkan, bila bertujuan meringankan pembeli sehingga tidak menambah harga disebabkan kredit tersebut. Sedangkan penjual mendapat pahala atas kebaikannya. Kredit diperbolehkan bila bertujuan mendapatkan laba penjualan sehingga harga dinaikan sebab pembayaran kredit. Pembayaran angsuran dibayar sesuai tempo yang disepakati bersama. Diperbolehkannya mengambil jaminan barang hingga utang pembeli dilunasi. ${ }^{22}$

Cara penentuan angsuran dalam bai' al-Murabahah, Syari'ah memperbolehkan bank untuk mengambil keuntungan atau laba atas transaksi tersebut. Dalam menentukan keuntungan ada beberapa cara, yakni sebagai berikut: ${ }^{23}$

1. Bank menentukan keuntungan dari jumlah dana yang dipinjam oleh nasabah untuk membeli barang ke bank tersebut sebesar yang disepakati. kedua belah pihak, misalnya $20 \%$ dari pokok pinjaman. Apabila yang ditambahkan adalah 2x keuntungan pertahun (20\%) maka hasilnya sama dengan 40\%. Cara seperti ini mempunyai kelemahan, kalau dibayar lebih dari satu tahun maka keuntungannya ditambah sebesar keuntungan satu tahun dikalikan dengan jumlah tahun, hal ini seolah-olah sebagai "tambahan karena meminjami" yang ditentukan dimuka sehingga mengarah kepada riba. Seandainya hal ini dengan

21 Sutan Remy Sjahdeini, Perbankan Islam: Dan Kedudukannya dalam Hukum Perbankan Indonesia. (Jakarta: Yayasan Adikarya IKAPI dan Ford Foundation, 1999), hlm. 177.

22 Syaikh Muhammad bin Ibrahim bin Abdullah At-Tuwajiri. Ensiklopedi Islam AL-KAMIL. (Jakarta; Darus Sunah Press. 2013), hlm. 901.

23Ibid, hal. 135-136. 
alasan untuk menstabilkan daya beli uang yang dipinjamkan bank mestinya persentase yang ditambahkan adalah sebesar estimasi inflasi yang akan datang atau dikurangi sebesar estimasi deflasi seandainya terjadi. Dengan rumus :

Harga jual = harga pokok aktiva murabahah (jumlah pembiayaan) + (markup atau laba X $n$ tahun).

2. Atas dana yang dipinjam oleh nasabah, bank syari'ah menerapkan keuntungan transaksi misal 20\%, kemudian kalau dibayar satu atau dua tahun maka untuk menstabilkan daya beli uang tersebut bank syari'ah dapat menambahkan sejumlah $2 \mathrm{x}$ inflasi dua tahun yang akan datang. misalnya, diperkirakan inflasi $5 \%$ pertahun maka faktor stabilizer daya beli untuk dua tahun $2 \times 5 \%=10 \%$, Jadi selama 2 tahun nasabah mengangsur pokok pinjaman ditambah keuntungan dan inflasi yaitu $10 \%+20 \%=30 \%$. Dengan rumus :

Harga jual $=$ harga pokok aktiva murabahah (jumlah pembiayaan) + (inflasi x n ) tahun + markup atau laba sekali.

3. Dalam penentuan harga jual bank, bank dapat menerapkan metode penetapan harga jual berdasarkan cost plus markup. Dengan metode cost plus, harga jual dapat dihitung dengan rumus, adalah sebagai berikut :

Harga jual = harga pokok aktiva mura $>$ bah $\} a h$ (jumlah pembiayaan) + cost recovery + markup atau laba sekali.

Cost recovery adalah bagian dari estimasi biaya operasi bank syari'ah yang dibebankan kepada harga pokok aktiva murabahah atau pembiayaan. Dengan rumus perhitungan cost recovery yaitu :

Cost recovery $=($ Harga pokok aktiva mura $>$ bah $\} a h$ atau pembiayaan / estimasi total 


$$
\begin{aligned}
& \text { pembiayaan ) x estimasi biaya } \\
& \text { operasi } 1 \text { tahun. }
\end{aligned}
$$

Markup atau laba ditentukan sekian persen dari harga pokok aktiva murabahah/ pembiayaan, misalnya 10\%. Untuk menghitung margin murabahah maka kita dapat menghitung dengan rumus :

Margin murabahah $=($ cost recovery + markup $) /$ harga pokok aktiva murabahah (pembiayaan). ${ }^{24}$

Sebagai contoh dalam bai' al-Murabahah, penjual harus memberi tahu harga produk yang ia beli dan menentukan suatu tingkat keuntungan sebagai tambahahannya. Misalnya pedagang eceran membeli komputer dari grosir dengan harga Rp.10.000.000,00, kemudian ia menambahkan keuntungan sebesar Rp. 750.000,00 dan ia menjual kepada si pembeli dengan harga 10.750.000,00. Pada umumnya, si pedagang eceran tidak akan memesan dari grosir sebelum ada pesanan dari calon pembeli dan mereka sudah menyepakati tentang lama pembiayaan, besar keuntungan yang diambil pedagang eceran, serta besarnya angsuran kalau memang akan dibayar secara angsuran. ${ }^{25}$

Adapun syarat - syarat bai' al-Murabahah yaitu :

1. Penjual memberitahu biaya modal kepada nasabah.

2. Kontrak pertama harus sah sesuai dengan rukun yang ditetapkan.

3. Kontrak harus bebas dari riba.

4. Penjual harus menjelaskan kepada pembeli bila terjadi cacat atas barang sesudah pembelian

\footnotetext{
24 Wiyono Slamet, Maulamin Taufan, Akuntansi Syariah di Indonesia,(Jakarta: Mitra Wacana Media, 2012.) Hal, 136.

25 Syafi'I Antonio, Bank Syariah Dari Teori ke Praktik, (Jakarta : Gema Insani, 2001), hal. 101.
} 
5. Penjual harus menyampaikan semua hal yang berkaitan dengan pembelian,misalnya jika pembelian dilakukan secara utang.

Pada pembiayaan murabahah terbagi menjadi dua, pembiayaan modal kerja, yaitu untuk mendapatkan modal dalam rangka pengembangan usaha, dan investasi, yaitu untuk investasi atau pengadaan barang konsumtif. ${ }^{26}$

Pada murabahah Kepada Pemesan Pembelian (KPP), janji pemesan untuk membeli barang dalam bai' al-Murabahah bisa merupakan janji yang mengikat, dan bisa juga tidak mengikat. Para ulama syari'ah terdahulu bersepakat bahwa pemesanan tidak boleh diikat untuk memenuhi kewajiban membeli barang yang telah dipesan itu. ${ }^{27}$

Murabahah KPP umumnya dapat diterapkan pada produk pembiayaan untuk pembelian barang-barang investasi, baik domestik maupun luar negeri, seperti melalui letter of credit (L/C). sedangkan di kalangan perbankan syari'ah di Indonesia banyak menggunakan al-Murabahah secara berkelanjutan seperti untuk modal kerja dan yang lainnya. ${ }^{28}$

Diperbankan syari'ah Indonesia, praktek akad murabahah didasarkan pada fatwa DSN MUI No 04/DSNMUI/IV/2000. Secara umum fatwa tersebut memberikan arahan baik kepada perbankan atau kepada nasabah. yang isinya sebagai berikut :

1. Ketentuan fatwa kepada bank

a. Bank dan nasabah melakukan akad murabahah yang berbasis bukan riba dan bukan barang haram.

b. Bank membiayai sebagian atau seluruh harga pembelian barang yang telah disepakati kualifikasi.

26 Abd. Hakim, atang, Fiqih Perbankan syari'ah (Bandung : PT Refika Aditama, 2011), hal. 221.

${ }^{27}$ Ibid, hal. 103.

${ }^{28}$ Ibid, hal. 106. 
c. Bank membeli barang tersebut atas nama bank sendiri.

d. Bank menjual barang kepada nasabah dengan harga beli ditambah dengan keuntungan yang diinginkan dan disepakati kedua belah pihak. Dalam hal ini bank harus secara jujur menyampaikan harga beli kepada nasabah.

e. Nasabah membayar harga barang tersebut dalam jangka waktu tertentu sesuai dengan kesepakatan.

f. Untuk menghindari terjadinya kecurangan, penyalahgunaan atau kerusakan bank dapat mengadakn perjanjian khusus.

g. Jika bank kesulitan menyediakan barang yang dibutuhkan oleh nasabah karena harus menyiapkan gudang, bank dapat mewakilkan kepada nasabah untuk membeli barang yang dibutuhkan oleh nasabah. Dalam hal seperti ini, murabahah dapat dilakukan jika secara prinsip barang harus sudah jadi milik bank. ${ }^{29}$

2. Ketentuan praktek murabahah terhadap nasabah yaitu

a. Nasabah mengajukan permohonan dan perjanjian pembelian suatu barang atau asset kepada bank. Kemudia jika bank menerima permohonan tersebut, bank harus membelikan terlebih dahulu asset tersebut. Danm jika keduanya sepakat maka dapat ditindak lanjuti dengan pembuatan kontrak jual beli.

b. Dalam kontrak jual beli tersebut, bank dibolehkan meminta nasabah untuk membayar uang muka terlebih dahulu saat penanda tanganan kontrak.

29 Afandi Yazid, Fiqh Muamalah dan Implementasi Dalam Lembaga Keuangan Syari'ah, (Yogyakarta: Logung Pustaka, 2009). hal, 95-96. 
c. Jika nasabah menolak membeli barang tersebut sebagai biaya riil barang yang telah dibeli. Jika nilai uang muka tersebut kurang, bank dapat meminta kembali sisa kerugiannya kepada nasabah.

d. Bank dapat meminta jaminan kepada nasabah, semata - mata agar nasabah tidak menghianati janji yang telah disepakati. Jaminan diterapkan sebagai tanda ikatan perjanjian kedua belah pihak agar para pihak agar para pihak tidak yang ingkar.

e. Hutang yang timbul dari akad murabahah secara prinsip penyelesaianya tidak ada kaitannya dengan transaksi lain yang dilakukan nasabah dengan pihak ketiga atas barang tersebut. Jika nasabah menjual kembali barang tersebut baik ada untung maupun mengalami kerugian, nasabah tetap mempunyai kewajian untuk menyelesaikan hutangnya kepada bank sebesar harga yang telah disepakati. Jika nasabah dapat menjual barang tersebut dengan segera, ia tidak wajib segera melunasi hutangnya kepada bank. Sebaliknya jika bank mengalami kerugian dalam pejualan barang tersebut, nasabah tidak mempunyai hak untuk menuntut bank memperhitungkan kerugian yang diterimanya.

f. Jika nasabah pada akhirnya dianggap pailit, dan dia tidak bisa segera melunasi hutangnya, bank harus memberikan toleransi kepada nasabah. Bank tidak boleh serta merta mengeksekusi jaminan yang di pegang bank. Toleransi ini diberikan semata-mata untuk meringankan beban nasabah. sedangkan batasan waktunya relatif tergantung kelonggaran nasabah. ${ }^{30}$

${ }^{30} \mathrm{Ibid}$, hal, 97-98. 


\section{Usaha Mikro, Kecil, dan Menengah (UMKM)}

UMKM adalah Usaha yang memproduksi barang dan jasa yang menggunakan bahan baku utamanya berbasis pada pendayagunaan sumber daya alam, bakat dan karya seni tradisional dari daerah setempat.Usaha Mikro sebagaimana dimaksud menurut Keputusan Menteri Keuangan No.40/KMK.06/2003 tanggal 29 januari 2003, yaitu usaha produktif milik keluarga atau perorangan Warga Negara Indonesia dan memiliki hasil penjualan paling banyak Rp.100.000.000,00 (seratus juta rupiah) per tahun. Usaha Mikro dapat mengajukan kredit kepada bank paling banyak Rp 50 juta. ${ }^{31}$

Menurut keputusan Presiden RI No. 99 tahun 1998, Usaha Kecil adalah kegiatan ekonomi rakyat yang yang berskala kecil dengan bidang usaha yang secara mayoritas merupakan kegiatan usaha kecil dan perlu di lindungi untuk mencegah dari persaingan usaha yang tidak sehat. ${ }^{32}$

Adapun kriteria menurut Undang-Undang ini sebagai berikut : 33

1. Memiliki kekayaan bersih paling banyak $\mathrm{Rp}$ 200.000.000,-(dua ratus juta rupiah), tidak termasuk tanah dan bangunan tempat usaha

2. Memiliki hasil penjualan tahunan paling banyak $\mathrm{Rp}$ 1000.000.000,-(satu milyar rupiah);

3. Milik warga Negara Indonesia

4. Berdiri sendiri, bukan merupakan anak perusahaan atau cabang perusahaan yang dimiliki, dikuasai, atau

\footnotetext{
31 Nurhasanah, Koperasi dan UMKM, (Perpustakaan Trunojoyo Madura : Fakultas ekonomi Universitas Trunojoyo, Makalah 2008/2009), hal. 15.

${ }^{32}$ Ibid, hal. 16.

${ }^{33}$ Amalia, Keadilan Distributif dalam Ekonomi Islam, (Jakarta : Rajawali pers, 2009), hal, 42.
} 
berafiliasi baik langsung maupun tidak langsung dengan Usaha Menengah atau Usaha Besar.

Departemen Perindustrian dan Perdagangan membagi

Usaha Kecil menjadi dua kelompok yaitu sebagai berikut : ${ }^{34}$

1. Industri Kecil adalah usaha indistri yang memiliki investasi peralatan kurang dari Rp70 juta, investasi per tenaga kerja maksimum Rp625 ribu, jumlah pekerja dibawah 20 orang serta asset dalam penguasaan nya tidak lebih dari 100 juta;

2. Perdagangan Kecil, yaitu usaha yang bergerak dibidang perdagangan dan jasa komersial yang memiliki modal kurang dari Rp80 juta dan perusahaan yang bergerak di bidang usaha produksi atau industri yang memiliki modal maksimal Rp200 juta.

Dalam pembangunan ekonomi rakyat dalam suatu Negara, peran usaha kecil dalam nampak dalam kontribusinya dalam mengatasi masalah ekonom makro, seperti pengangguran atau penyerapan tenaga kerja dan peningkatan inovasi. Berikut dikemukakan beberapa peran dan fungsi usaha kecil sebagai tulang punggung perekonomian masyarakat :

1. Penyerapan tenaga kerja

Usaha kecil memiliki peran dalam menyerap tenaga kerja atau sekeompok orang yang mampu melakukan pekerjaan guna menghasilkan suatu barang dan jasa untuk memenuhi kebutuhan masyarakat.

2. Pemerataan pendapatan

Jumlah usaha kecil di Indonesia sangat besar kuantitasnya. Mereka tersebar dalam berbagai jenis usaha dan wilayah operasi. Kondisi tersebut mengakibatkan banyak masyarakat yang dapat ikut

34ibid, hal, 43 
akses kedalamnya sehingga menghindari terjadinya pengangguran atau memperoleh pendapatan.

3. Nilai tambah bagi produk daerah

Setiap daerah tentu memiliki keunggulannya masingmasing, baik dilihat dari letak geografis maupun potensi sumber daya alamnya. Apabila potensi sumber daya alam suatu daerah dikelola oleh pengusaha kecil secara professional maka kondisinya akan memberikan nilai tambah, baik bagi produk itu sendiri maupun bagi nilai tambah produk unggulan yang ada di daerah tersebut.

4. Peningkatan taraf hidup

Dengan adanya lapangan pekerjaan di berbagai sektor, termasuk usaha kecil, diharapkan dapat menyerap tenaga kerja, baik tenaga kerja yang masih menganggur maupun semi menganggur sehingga mereka dapat menambah penghasilan guna memenuhi kebutuhan diri dan keluarga. 35

\section{METODE PENELITIAN}

Penelitian ini menggunakan desain kuantitatif dimana teknik pengumpulan data yang digunakan adalah dokumentasi, wawancara dan angket. Teknik analisis dan pengolahan data yang digunakan adalah SPSS yang terdiri dari regresi linier sederhana, uji korelasi, uji t dan persentase excel.

Analisis ini untuk mengetahui arah hubungan antara variabel independen dengan variabel dependen apabila nilai variabel independen mengalami kenaikan atau penurunan. Dan model regresi sederhana pada umumnya dapat ditulis melalui persamaan berikut:

$$
\begin{aligned}
& \mathrm{Y}=\mathrm{a}+\mathrm{bX} \quad \text { Dengan keterangan : } \\
& \mathrm{Y} \quad=\text { Variabel dependen (Pendapatan UMKM) }
\end{aligned}
$$

${ }^{35}$ Muhammad, Lembaga Keuangan Mikro Syari'ah, (Yogyakarta: Graha Ilmu, 2009). hal, 35. 
$\mathrm{X}=$ Variabel independen (Modal pembiayaan Murabahah)

a = Konstanta (nilai Y apabila $\mathrm{X}=0$ )

$\mathrm{b} \quad=$ koefisien regresi (nilai peningkatan ataupun penurunan)

Penggunaan rumus ini untuk mengetahui apakah variabel mempengaruhi atau tidak. Metode analisa dalam penelitian ini adalah metode kuantitatif, yaitu metode untuk menganalisa angka-angka yang ditunjukkan oleh data serta menganalisa korelasi antara hubungan variabel dan alat ukur yang ada. Analisis korelasi yaitumetode statistika yang dilakukan dengan tujuan untuk menentukan kuat atau lemahnya hubungan antara dua variable atau lebih.

\section{HASIL DAN ANALISIS}

Berdasarkan hasil analisis yang telah dilakukan dengan menggunakan metode regresi linier sederhana program SPSS 16.0 for Windows (Statistika Program for Social Science) dapat diperoleh hasil sebagai berikut:

Hasil perhitungan regresi linier sederhana dari pengolahan data pada tabel 1 yaitu modal tambahan (pembiayaan murabahah terhadap pendapatan Usaha Mikro Kecil Menengah menghasilkan nilai sebagai berikut: 
Tabel 1. Hasil Analisis regresi linear berganda

\section{Coefficients $^{\mathbf{a}}$}

\begin{tabular}{|c|c|c|c|c|c|}
\hline \multirow[t]{2}{*}{ Model } & \multicolumn{2}{|c|}{$\begin{array}{l}\text { Unstandardized } \\
\text { Coefficients }\end{array}$} & \multirow{2}{*}{\multicolumn{2}{|c|}{$\begin{array}{l}\text { Standardized } \mathrm{t} \\
\text { Coefficients } \\
\text { Beta }\end{array}$}} & \multirow[t]{2}{*}{ Sig. } \\
\hline & $\mathrm{B}$ & Std. Error & & & \\
\hline (Constant) & -491.456 & 1359.588 & & -361 & 0,719 \\
\hline$X$ & $-0,085$ & 0,004 & & -7.811 & 0,000 \\
\hline
\end{tabular}

Variabel terikat : M

Konstanta

$\mathrm{R}$
: -491.456

: 0,473
F hitung : 61.010

Sig : 0,000

$\mathrm{N} \quad: 70$

Sumber; SPSS (data diolah)

Berdasarkan nilai - nilai yang di tampilkan dalam tabel 1, maka dapat di bentuk persamaan regresi linier sederhada sebagai berikut :

$$
\begin{aligned}
& Y=\mathbf{a}+\mathrm{Bx} \\
& Y=-491.456+0,028 X
\end{aligned}
$$

Dengan keterangan :

$\mathrm{Y} \quad=$ Variabel dependen (Pendapatan Usaha Mikro Kecil Menengah)

$\mathrm{X}=$ Variabel independen (Modal pembiayaan murabahah)

$\mathrm{a} \quad=$ Konstanta (nilai Y apabila X $=0$ )

$\mathrm{b}=$ Koefisien regresi (Nilai peningkatan ataupun penurunan)

Dengan persamaan regresi linier sederhana di atas, persamaan regresi tersebut menunjukkan bahwa variabel $\mathrm{X}$ yaitu pembiayaan murabahah mempunyai koefisien regresi yang sangat baik, hal ini berarti kondisi adanya tambahan 
modal pembiayaan murabahah sangat baik terhadap pengaruh perkembangan Usaha Mikro Kecil Menengah.

Angka konstan yang bertanda negative berarti menunjukkan terjadinya hubungan yang sangat erat atau berpengaruh dari variabel X pembiayaan murabahah terhadap variabel Y pendapatan Usaha Mikro Kecil Menengah.

Dan berdasarkan persamaan regresi di atas, maka dapat di jelaskan sebagai berikut :

a. Konstanta sebesar -491.456, artinya jika variabel X pembiayaan murabahah nilainya adalah 0 , maka variabel $Y$ pendapatan Usaha Mikro Kecil Menengah nilainya adalah 491.456, jadi dapat di simpulkan jika Usaha Mikro Kecil Menengah tanpa adanya tambahan modal yaitu pembiayaan murabahah maka pendapatan nya akan tetap.

b. Koefisien regresi variabel $\mathrm{X}$ sebesar 0,028 menyatakan bahwa setiap penambahan 1 nilai terhadap varibel $X$ pembiayaan murabahah, maka nilai variabel Y pendapatan Usaha Mikro Kecil menengah akan bertambah sebesar 0.028, jadi dapat disimpulkan bahwa jika Usaha Mikro Kecil Menengah mendapatkan tambahan modal pembiayaan murabahah maka pendapatan nya akan bertambah atau akan meningkat. 
Tabel 2.

\begin{tabular}{|l|r|r|r|r|}
\hline \multicolumn{5}{|c|}{ Model Summaryb } \\
\hline Model & R & R Square & $\begin{array}{c}\text { Adjusted R } \\
\text { Square }\end{array}$ & $\begin{array}{c}\text { Std. Error of the } \\
\text { Estimate }\end{array}$ \\
\hline 1 & $.688 \mathrm{a}$ & .473 & .465 & 7440.284 \\
\hline $\begin{array}{l}\text { a. Predictors: (Constant), X } \\
\text { b.Dependent } \\
\text { Variable: Y }\end{array}$ \\
\hline
\end{tabular}

Dari tabel 2 di atas dapat di jelaskan besarnya nilai korelasi atau hubngan (R) yaitu sebesar 0,688 dan dapat di jelaskan pula besarnya prosentase pengaruh variabel $\mathrm{X}$ terhadap variabel $Y$ yang disebut koefisien diterminasi yang merupakan hasil penguadratan dari $(R)$ yaitu $R^{2}=0,688 \mathrm{x}$ $0,688=0,4733$. Jadi koefisien diterminasinya adalah sebesar 0,473 yang mengandung pengertian bahwa pengaruh variabel $\mathrm{X}$ pembiayaan murabahah terhadap variabel $\mathrm{Y}$ pendapatan Usaha Kecil Menengah adalah sebesar 0,473. Dan karena nilai $\mathrm{R}=0,688$ mendekati +1 , maka hubungan antara variabel $\mathrm{X}$ pembiayaan murabah\}ah dan variabel Y pendapatan Usaha Mikro Kecil Menengah adalah sempurna dan positif atau disebut juga mendekati 1yaitu hubungan yang sangat kuat dan searah.

Berdasarkan pada data yang telah diolah dengan menggunakan program SPSS 16.0 maka dilakukan pengujian Hipotesis yang telah ditetapkan. Dan karena dalam penelitian ini hanya memiliki satu variael $X$ sebagai variabel pengaruh, jadi pengujian hipotesisnya hanya menggunakan uji t yang mana uji t ini untuk mengetahui apakah ada pengaruh yang 
nyata (signifikan) variabel $\mathrm{X}$ pembiayaan murabah\}ah terhadap variabel Y pendapatan Usaha mikro Kecil Menengah. Dengan sebagai berikut:

Ho : Tidak ada pengaruh yang nyata (signifikan) variabel $\mathrm{X}$ pembiayaan murabahah terhadap variabel $\mathrm{Y}$ pendapatan Usaha Mikro Kecil Menengah.

$\mathrm{H}_{\mathrm{a}}$ : Ada pengaruh yang nyata (signifikan) variabel $\mathrm{X}$ pembiayaan murabahah terhadap variabel Y pendatan Usaha Mikro Kecil Menengah.

\section{Uji t :}

Uji t-statistik digunakan untuk mengetahui apakah variabel independen X pembiayaan murabahah berpengaruh secara signifikan terhadap variabel Y pendapatan Usaha Mikro Kecil Menengah.

\section{Tabel 3.}

\section{Coefficients $^{\mathrm{a}}$}

\begin{tabular}{|c|c|c|c|c|c|}
\hline \multirow[b]{2}{*}{ Model } & \multicolumn{2}{|c|}{$\begin{array}{c}\text { Unstandardized } \\
\text { Coefficients }\end{array}$} & \multirow{2}{*}{$\begin{array}{c}\text { Standardize } \\
\mathrm{d} \\
\text { Coefficients } \\
\text { Beta }\end{array}$} & \multirow[b]{2}{*}{$\mathrm{T}$} & \multirow[b]{2}{*}{ Sig. } \\
\hline & B & Std. Error & & & \\
\hline 1 (Constant) & $-491.456-$ & 1359.588 & & $-.361-$ & .719 \\
\hline $\mathrm{X}$ & .028 & .004 & .688 & 7.811 & .000 \\
\hline
\end{tabular}

Dilihat dari tabel 3 di atas hasil regresinya dapat diketahui nilai t hitung, dan untuk mengetahui nilai t tabel yaitu dengan langkah-langkah sebagai berikut:

- $\quad$ Menentukan tingkat signifikasi a = 5\% yaitu 0,05 
- Berdasarkan tabel di atas di peroleh $\mathrm{t}$ hitung sebesar 7.811

- Menentukan $\mathrm{T}$ tabel dengan tabel distribusi $\mathrm{t}$ dicari pada a $=50 \%$ yaitu 0,05 (uji 2 sisi)

- dengan derajat kebebasan (df) n-k yaitu 70-2 = 68

(n) jumlah responden (k) jumlah variabel dependen dan independen

- dengan melihat pada tabel maka t tabel sebesar 1.995

Jadi dapat disimpulkan sebagai berikut :

Nilai $t_{\text {hitung }}$ lebih besar dari tabel yaitu $(7.811>1.995)$ pada tingkat sig pembiayaan murabahah dan sig t tabel yaitu $(0.000<0.05)$ maka $\mathrm{H}_{0}$ ditolak dan Ha diterima. Hal ini menunjukkan bahwa variabel X pembiayaan Murabahah mempunyai pengaruh yang signifikasi terhadap perkembangan Usaha Mikro Kecil Menengah.

Berdasarkan hasil uji penelitia ini dari uji regresi linier sederhana, uji korelasi, uji t-statistik, dan uji persentase telah membuktikan bahwa pengaruh variabel $X$ pembiayaan murabahah terhadap variabel Y pendapatan Usaha Mikro Kecil Menengah pengaruhnya sangat baik dan terbukti pengaruhnya sangat signifikan dan memiliki korelasi hubungan yang positif.

Dengan demikian dapat dijelaskan bahwa pembiayaan mura $>b a h\} a h$ di PT. BRI Syari'ah KCP Bangkalan sangatlah membantu dalam perkembangan Usaha Mikro Kecil Menengah, hal ini sudah dapat dibuktikan bahwa setelah melakukan pembiayaan Mura>bah\}ah pendapatan Usaha Mikro Kecil Menengah mengalami peningkatan sebesar 236\% . Dengan kata lain salah satu faktor yang membuat para pengusaha mikro kecil menegah semakin berkembang adalah adanya tambahan modal atau yang disebut dengan pembiayaan murabahah. 


\section{KESIMPULAN}

Jadi keadaan Usahaa Mikro Kecil Menengah masyarakat Bangkalan dengan modal dan pendapatan yang sangat paspasan membuat sebagian para UMKM mengabil pembiayaan di PT. BRI Syari'ah hingga lebih dari 100\%. Berdasarkan pengujian secara hipotesis Uji t-statistik, bahwa variabel X pembiayaan murabahah mempunyai pengaruh yang signifikan terhadap variabel Y perkembangan Usaha Mikro Kecil Menengah. Sehinggapengaruhnya pembiayaan murabahaah di PT. BRI Syari'ah KCP Bangkalan terhadap perkembangan Usaha Mikro Kecil Menengah dapat di persentasekan sebesar $236 \%$.

\section{DAFTAR PUSTAKA}

Abd. Hakim, atang, Fiqih Perbankan syari'ah (Bandung : PT Refika Aditama, 2011).

Ade Raselawati,"Pengaruh perkembangan Usaha Kecil Menengah terhadap pertumbuhan ekonomi pada sektor UKM di Indonesia", Skripsi.

Afandi Yazid, Fiqh Muamalah dan Implementasi Dalam Lembaga Keuangan Syari'ah, (Yogyakarta: Logung Pustaka, 2009).

Arifin, N. R., Muhtadi, R., \& Herianingrum, S. (2019). Small and Medium Enterprise Perception of Halal Certification Post Formalization of Islamic City Branding. IJIBE (International Journal of Islamic Business Ethics), 4(1), 601-610.

Agus Widarjono, Ekonometrika Pengantar dan Aplikasinya, Edisi 4 (Yogyakarta: UPP STIM YKPN, 2013).

Amalia, Keadilan Distributif dalam Ekonomi Islam, (Jakarta : Rajawali pers, 2009). 
Anita Rahmawati, Ekonomi Syariah: Tinjauan Kritis Produk Mura>bah\}ah dalam Perbankan Syari'ah di Indonesia,( La_Riba 2007).

Bank Indonesia,"kredit UMKM", dalam www.bi.go.id

BBC,"Potensi UMKM di Indonesia", dalam www. bbcIndonesia.com

Faiseh, N., Kamali, K., \& Muhtadi, R. (2021). Implementasi Sistem Angsuran Terhadap Pendapatan Usaha Mikro, Kecil Dan Menengah Di Bmt Al-Iktisab. KOIN: Jurnal Ekonomi Syariah Teori Dan Terapan, 1(01), 102-119.

Hadi, Sutrisno, Metodologi research,(Yogyakarta : Andi, 2004).

Hafiz Abi ‘Abdillah Muhammad bin Yasi>d AL-Qozwi>n, Sunan Ibnu Majah.

Ibnu Rusyd, Terjemahan Bidayatul Mujtahid jilid III, (Semarang: As-Syifa', 1990).

Imam Pirman dan Adi Ridwan, "Pengaruh Penyaluran Kredit Usaha Mikro Kecil Menengah (UMKM) dan Pendapatan Operasional Terhadap Laba Operasional (Kasus Pada PT Bank Jabar Banten. TBK).

Kusrianto, Adi, Mempraktikan rumus - rumus excel dalam bekerja, (Jakarta : PT. Prestasi Pustakaraya, 2013).

Muhammad, Lembaga Keuangan Mikro Syari'ah, (Yogyakarta: Graha Ilmu, 2009).

Mahmal Rizka, "Upaya Meminimalisir Risiko Pembiayaan Produktif Untuk UKM Oleh Bank Syari'ah (Studi Kasus Pada Bank DKI Syari'ah Cabang Wahid Hasyim), dalam menyelesaikan gelar strata 1 di Universitas Islam Negri Syarif Hidayatullah Jakarta, 2009. 
Muhtadi, R. (2012). Sinergisme Baitul Maal wa tamwil (BMT) dengan badan usaha milik desa (BUMDES) sebagai alternatif penguatan UMKM Masyarakat Pedesaan di Madura. Jurnal Sains Ekonomi Islam Pascasarjana Universitas Airlangga.

Munawwaroh, M., Muhtadi, R., \& Marsam, M. (2021). ANALISIS MANAJEMEN RESIKO PEMBIAYAAN MUROBAHAH PADA BANK SYARIAH PT. BPRS SARANA PRIMA MANDIRI. KOIN: Jurnal Ekonomi Syariah Teori dan Terapan, 1(01), 66-82.

Muslikhin, M., Kinanti, R. A., Muhtadi, R., \& Fudholi, M. (2020). Pemeriksaan Empiris Pada Pengaruh Kinerja Sosial Terhadap Profitabilitas Di Bank Syariah. Ulumuna: Jurnal Studi Keislaman, 6(1), 72-84.

Nurhasanah, Koperasi dan UMKM, (Perpustakaan Trunojoyo Madura : Fakultas ekonomi Universitas Trunojoyo 2008/2009.

Orchidya Sari, "pelaksanaan penjaminan kredit Usaha Mikro Kecil dan Menengah Oleh Lembaga Penjamin Kredit", program pasca sarjana Fakultas Hukum Universitas Andalas, 2011.

Sri Wahyuningsih,"Dosen Fakultas Pertanian Universitas Wahid Hasim", Jurnal Peranan UKM Dalam Perekonomian Indonesia.

Sayyid Sabiq, Fiqh Sunnah Terjemahan Kamaluddin Jilid 12, (Bandung: Al-Ma'rif, 1995).

Sugiono, Metode Penelitian Kuantitatif, Kualitatif dan (R\&D), (Bandung : Alfabeta, 2008).

Sugiyono, Statistika Untuk Penelitian(Bandung: Alfabeta, 2009). 
Sutan Remy Sjahdeini, Perbankan Islam: Dan Kedudukannya dalam Hukum Perbankan Indonesia. (Jakarta: Yayasan Adikarya IKAPI dan Ford Foundation, 1999).

Sutedi, Adrian, Perbankan Syari'ah tinjauan dan beberapa segi hukum, (Bogor : Ghalia Indonesia, 2004).

Syafi'I Antonio, Bank Syariah Dari Teori ke Praktik, (Jakarta : Gema Insani, 2001).

Syaikh Muhammad bin Ibrahim bin Abdullah At-Tuwajiri. Ensiklopedi Islam AL-KAMIL. (Jakarta; Darus Sunah Press. 2013).

Syukri iska, Sistem Perbankan Syariah Di Indonesia, Yogyakarta: Fajar Media Pers, 2012.

Undang-Undang Republik Indonesia, "Usaha Mikro, Kecil , dan Menengah”, No 20 tahun 2008.

Wiyono Slamet, Maulamin Taufan, Akuntansi Syariah di Indonesia, Jakarta: Penerbit Mitra Wacana Media, 2012. 